\title{
MOLECULAR STRUCTURE OF THE EPIDERMAL EXTRACELLULAR SPACES
}

\author{
L. A. DIAZ, M.D.
}

From the Department of Dermatology, University of Michigan Medical School, Ann Arbor, Michigan

The skin is a protective cover that participates in the homeostatic regulation of internal fluids by preventing the passage of water, electrolytes and proteins into the external environment. The functional integrity of the skin is maintained through the interaction of the epidermis with the dermis. The epidermis is a tissue arranged in cellular layers. Those epidermal cells in direct opposition to the dermis are the basal cells. The epidermal basal cells are undifferentiated and endowed with mitotic activity. Obeying unknown stimuli, the basal cells undergo maturation following a differentiation pathway that ends with the formation of the stratum corneum. The stratum corneum is an inert film, made of fully differentiated epidermal cells. These cells are anucleated and contain tightly packed fibrous proteins embedded in an amorphous matrix and thick cell membranes. The structure of the epidermis allows a dynamic renewal of stratum corenum throughout life.

The epidermal basal cells are seated on the basal lamina (basement membrane) and are

Supported by NIH grant 1 R01 AM 21608-01A1.

Address for reprints: L. A. Diaz, M.D., Kresge Research Building, R-5538, University of Michigan, Ann Arbor, MI 48109. attached to it by an as yet undefined "glue substance." This substance(s) fills the space known as lamina lucida, an electron-lucent space that separates the basal cell membrane from the basal lamina. The basal cells, differentiating keratinocytes and the stratum corneum are attached to each other by another undefined "glue substance." This substance(s) fills the epidermal intercellular spaces (ICS).

The epidermal cells are enclosed in a space limited externally by the stratum corneum and internally by the basal lamina (Fig. 1). Molecules moving in and out of the epidermal compartment must permeate these biological filters. A review of the cutaneous basal lamina was recently published in this Journal, ${ }^{1}$ and excellent articles on permeability of the stratum corneum are also reported elsewhere. $^{2,3}$ The aim of this article is to suggest a hypothetical "molecular model" for the epidermal intercellular spaces (ICS). This model integrates some known structural aspects of the ICS and recent findings in the field of cell surface biology. Although the biochemical nature of the ICS remains relatively unexplored, recent advances in cell surface biology and epidermal pathophysiology strongly suggest that these spaces are important to maintain a functionally normal skin. An attempt will be made to explore the complex cell adhesion phenomenon and its relevance in epidermal cell pathology. We

0011-9059/79/0700/0434/\$00.95 (C) International Society of Tropical Dermatology, Inc. 
Fig. 1. Structural aspects of human skin.

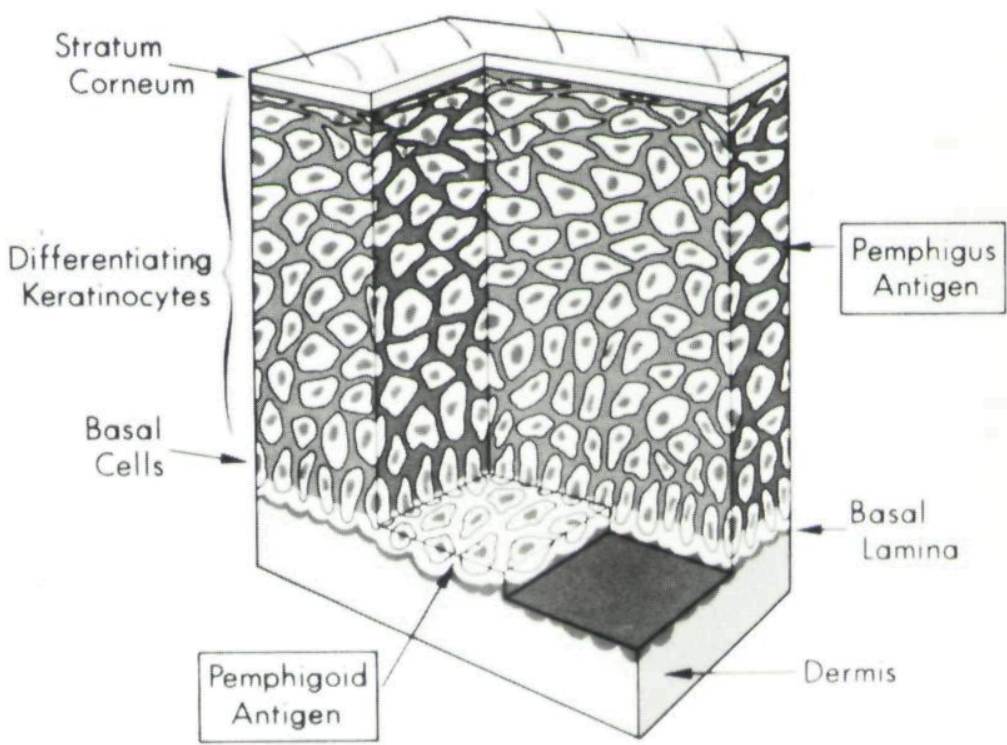

acknowledge that some of the concepts developed in the course of this review probably are an oversimplification to what may be happening in vivo in the dynamic epidermis.

\section{Cutaneous Basal Lamina}

Studies by Briggaman ${ }^{4}$ and others ${ }^{5-8}$ have shown the cutaneous basal lamina $(\mathrm{CBL})$ to be of epidermal origin. Little is known about the chemical nature of the CBL; however, by analogy to other basement membranes, it is assumed that it has a collagen Type IV chemical composition. ${ }^{9-11}$ Two functions are attributable to basement membranes. ${ }^{12,13}$ The first function is the provision of mechanical support to overlying epidermal cells. For example, in the basement membrane zone of the chick cornea, a cell to tissue-substrate framework support is formed. This framework may result from macromolecular interactions, presumably ionic in nature, between chondrotin sulfate protein (basal cell surface) and the collagen of the basement membrane (Type IV collagen) and/or that of the primary corneal stroma (Type I collagen). ${ }^{14}$ The supramolecular structure thus formed would adhere and confer mechanical support to the overlying epithelia. ${ }^{15}$ The second function is the regulation of the molecular movement be- tween compartments separated by this membrane in a fashion perhaps not unlike glomerular filtration in the kidney. Preliminary work on the permeability of the $\mathrm{CBL}$ suggests that filtration of molecules across this membrane may be a molecular size-charge phenomenon. ${ }^{16-18}$ It is important to note that certain autoantibodies (pemphigus, pemphigoid) as well as complement components, must permeate the $\mathrm{CBL}$ in order to reach their cell surface target. Nothing is known about the regulation of the cell locomotion phenomenon across the CBL.

\section{Epidermal Extracellular Spaces}

The epidermal and dermal compartments can be further subdivided by the individual cell membrane boundaries into intracellular and extracellular compartments. The latter compartment is also called the intercellular or extracellular space (ICS). The epidermal extracellular compartment is reduced because of the close contact between differentiating epidermal cells as well as between basal cells and the CBL. The space between the basal cell membrane and the $\mathrm{CBL}$ is also called the lamina lucida. It is this space which contains the "viscous bond" responsible for the attachment of epidermis to the basement mem- 
brane. ${ }^{19-25}$ The nature of the "viscous bond" is unknown. Bullous pemphigoid antigen is a normal component of this space. ${ }^{26}$ Substances filling this space including pemphigoid antigen are intimately associated with the outer leaflet of the basal cell membrane. ${ }^{4,14-16,27,28}$ The cell surface of epidermal cells, melanocytes, Langerhans' cells, and Merkel cells, occupying the epidermal compartment are in close proximity to each other and share a common epidermal ICS which is continuous with the lamina lucida. ${ }^{16}$ Morphologically, the epidermal cells are separated from the extracellular space by a trilaminar cell membrane unit. ${ }^{29}$ The intermembranous space between adjacent cells are between basal cells and CBL (lamina lucida) is filled with a material which, upon histochemical staining, appears to be rich in carbohydrates. This carbohydrate-rich coat is closely connected to the outer leaflet of the cell membrane ${ }^{30-34}$ and constitutes the so-called glycocalyx. ${ }^{30}$ At irregular intervals, adjacent cells share common organelles called desmosomes or macula adhaerens. ${ }^{35} \mathrm{~A}$ desmosome is formed by two dense proteinaceous plaques, parallel to the inner leaflet of their respective cell membranes. ${ }^{36} \mathrm{~A}$ bundle of tonofilaments converges from the cytoplasm into the desmosome plaque, looping back into the cytoplasm. ${ }^{37}$ Although the fibrilar component of the desmosome unit has been implicated in the formation of the fibrous component of keratin, ${ }^{38}$ its relationship to other filamentous proteins such as actin, myosin, tubulin, etc., cannot be discounted. ${ }^{39}$ Epidermal cells have been found to contain microtubules ${ }^{40}$ and actin and myosin. ${ }^{41-43}$ However, their relationship to tonofilaments and epidermal cell membranes remains to be determined. The basal cells show only half a desmosome; their morphology, however, is similar to that of the basic desmosome unit of higher epidermal cells. ${ }^{28}$

The epidermal cell membrane undergoes major changes during differentiation (keratinization), ${ }^{29,44}$ and the desmosomes are involved in this process. ${ }^{45-47}$ Mitosis and migration of basal cells are accompanied by au- tophagocytosis of the desmosome unit. ${ }^{45,48} \mathrm{At}$ the level of the stratum granulosum and stratum corneum, there is a thickening of cell membranes and intercellular spaces and lysis of desmosomes. ${ }^{29,45}$ Thus, the intercellular spaces at this level contain, in addition to the degraded desmosomes, enzymatic products from membrane coating granules, ${ }^{45,47}$ and constitute, along with keratin, ${ }^{49}$ the stratum corneum, the final product of epidermal differentiation.

In 1972, Singer and Nicolson ${ }^{49}$ proposed the presently accepted model of cell membrane structure, the fluid mosaic model, based primarily on thermodynamic considerations. Glycoproteins and glycolipids are associated with cell surfaces forming the glycocalyx of cells. The glycocalyx contains a complex set of components such as receptors for hormones, antibodies and lectins, as well as blood group and HLA antigens. The epidermal cell surface contains HLA, blood groups and pemphigus antigen(s) and receptor molecules for lectin and hormones. ${ }^{51-60}$

It has been clearly established that the cell surface-cytoskeletal system interactions play a critical role in many aspects of cell behavior, such as cell recognition, cell adhesion, cell locomotion, cell morphology and embryologic differentiation. ${ }^{61-74}$ Any defect in the molecular structure of the cell surface or disruption of the cytoskeletal system (actin, myosin, tubulin, etc.) may trigger pathologic changes in cells, causing them to display abnormalities in their biologic behavior, such as cell adhesion. ${ }^{71,75,76}$ Many of these abnormalities are also found in transformed cells. ${ }^{64,76-81}$

In the epidermis, adjacent epidermal cells share desmosome units composed of tonofilaments, attachment plaques, cell membranes and intercellular substances(s). These components are bound together, constituting a firm point of attachment between epidermal cells. ${ }^{82}$ The molecular aspects of this phenomenon remain unknown. Cell recognition in the epidermis is shown during the de- 
velopment of desmosomes. These studies demonstrate a lack of desmosome formation between unrelated cells such as epithelial cells and pigmentary ${ }^{83}$ or Langerhans' cells. ${ }^{84}$

\section{Cell Surface-Cell Adhesion}

At the molecular level, the in vivo cell-tocell or cell-to-substrate adhesion is a complex cell surface biochemical phenomenon. Several hypotheses have been postulated to explain this phenomenon. Tyler and Weiss ${ }^{85,86}$ thought that the cell membranes of adjacent cells contained antigen and antibody-like molecules on their cell surface. The formation of immune complexes between the surface of opposite cells would result in intercellular adhesion. Later Roseman ${ }^{87}$ postulated the enzyme-substrate theory to explain cell adhesion, in which a cell surface glycosyl transferase enzyme system would catalyze the specific transfer of simple sugars to acceptorsubstrates. As a result of this enzymatic activity, the adhesion of cells might occur. Recently, Bell ${ }^{88}$ has proposed that cell adhesion may be mediated by formation of reversible bonds between cell surface molecules.

Two types of cell adhesion have been described in vitro ${ }^{89}$ : (a) nonspecific adhesion between cells and substrates, such as glass, plastics, collagen-coated slides, etc., and (b)

Table 1. Epidermal Cell-To-Cell Adhesion

Cell 1
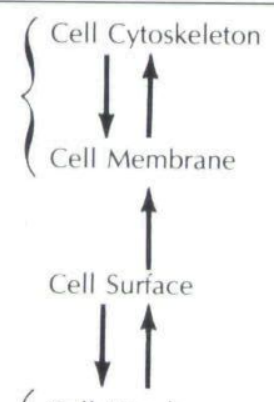

Cell 2
Table 2. Epidermal-Dermal Adhesion

Basal Cell

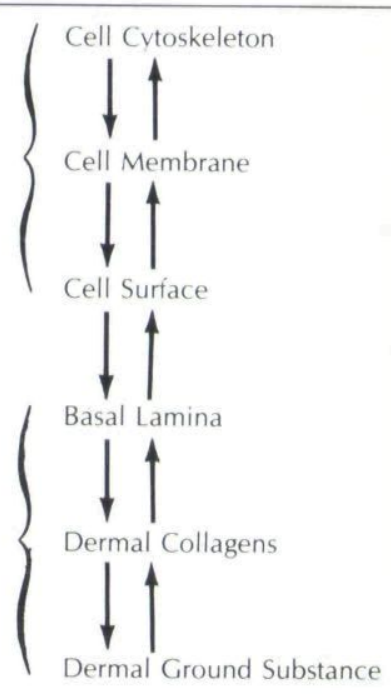

intercellular adhesion which may be specific, if the interacting cells are homologous, or nonspecific, if the cells involved are heterologous. The adhesion phenomenon studied with the use of the tissue culture system thus appears to depend upon a complex, multistep biochemical phenomenon ${ }^{90-92}$ in which interactions between serum factors, ${ }^{93,94}$ cell surface microexudates, ${ }^{\mathbf{9 5}-98}$ $\mathrm{Ca}++$ and $\mathrm{Mg}++{ }^{99,101}$ and environmental physical factors such as temperature are important. ${ }^{89,102-104}$

Certain purified cells surface antigens ("'aggregating factors") ${ }^{105-112}$ or cell membrane fractions ${ }^{113-115}$ have been shown to promote specific cell adhesion when added to cells of the type from which the factor was extracted. Isolated cell surface glycoproteins involved in cell adhesion have also been described in slime molds, ${ }^{116}$ fibroblasts (LETS protein), ${ }^{98,100,117-122}$ neural cells, ${ }^{123-125}$ etc. Furthermore, cells deficient in these cell surface glycoproteins $75,126,127$ show an abnormal, rounded morphology and impaired adhesiveness. Upon reincorporation of the deficient cell surface glycoproteins, ${ }^{75,76}$ the cells return to their normal morphology and regain their normal adhesion properties. Cell trans- 
formation is associated with a decrease in those cell surface glycoproteins ${ }^{79,128,129}$ and with defective cell adhesion. ${ }^{75-81,91} \mathrm{Im}$ munological studies have provided further information implicating certain cell surface molecules in the cell adhesion phenomenon. Antibodies produced against cell surface antigens are known to induce the following changes when added to antigen-bearing cells: (a) cellular cytotoxicity in the presence of complement, ${ }^{130,131}$ (b) induction of antigenic modulation, ${ }^{132}$ (c) cell surface aggultination with a corresponding increase in $\mathrm{mi}$ crovilli, ${ }^{133-135}$ (d) impaired phagocytosis, ${ }^{133,134}$ (e) impairment of inhibition of cell adhesion (aggregation), ${ }^{76,124,125,135-138}$ (f) prevention of the restoration of morphology and adhesiveness in transformed cells upon the addition of the deficient cell surface glycoproteins, ${ }^{75,76}$ (g) alteration of the normal morphology of cells causing them to become rounded, ${ }^{76,135}$ and $(h)$ alteration of embryogenesis. ${ }^{139}$

The types of adhesion phenomena that need to be explored in the skin are: (a) the cell-to-cell adhesion between epidermal cells and (b) the adhesion of basal cells to the dermis. Both are possibly related to a cell surface "glue" produced by the epidermal cells. The nature of this "glue" and its interactions with other unrelated molecular structures (intracellular and extracellular) remain to be studied in the future. Two oversimplified outlines that we follow when studying cell adherence in the skin are shown in Tables 1 and 2. The molecular dissection of each of the components listed and the factors that regulate their interactions probably are important in maintaining the normal epidermal cell adhesion in vivo. It is predicted that any disturbance in each of these interacting systems will be manifested in a clinical disease. Thus, "dissolution" of the cell surface "glue" that normally attaches differentiating keratinocytes is found in diseases such as pemphigus vulgaris, Hailey and Hailey and certain forms of toxic epidermal necrolysis. "Dissolution" of the basal cell surface "glue" that attached these cells to the basal lamina is observed in the skin of patients with bullous pemphigoid, and epidermolysis bullosa letalis. These are a few of the dermatoses that maybe considered "experiments" of nature and from which we may learn important aspects of epidermal cell biology.

\section{Dynamic Concept of the Epidermal Extracellular Spaces}

In addition to cell membrane components, the epidermal extracellular spaces may contain molecules of epidermal and extraepidermal origin (external environment, serum, dermis) which have permeated the CBL or stratum corneum. The molecular structure of the epidermal ICS and the way it may regulate the movement of the extracellular molecules ${ }^{140,141}$ remains to be explored. The ICS maybe conceived as a dynamic "biological molecular mesh" formed by interacting cell surface molecules of cells sharing the epidermal compartment. This dynamic state would depend on the integrity of the epidermal and nonepidermal cell membranes, the permeability of the stratum corneum and the basal lamina, and perhaps the degree of differentiation, and the metabolic state of the cells enclosed in this compartment. The importance of the permeability of the CBL and those factors that may control or regulate its filtration properties remains unknown. The CBL may play a critical role in keeping epidermal antigens away from pathogenic cytotoxic antibodies as postulated by Terasaki and Chamberlain. ${ }^{142}$ These authors found that autologous serum was cytotoxic to epidermal cells in vitro. Thus any disturbance in the CBL permeability may cause accumulation of fluid, penetration of cytotoxic autoantibodies and chemotatic cell migration into the altered epidermal extracellular compartment.

\section{References}

1. Hodge, S. J., and Freeman, R. G.: The basal lamina in skin disease. Int. J. Dermatol. 17:261, 1978.

2. Scheuplein, R. J.: Permeability of the skin: a review of major concepts and some new developments. J. Invest. Dermatol. 67:672, 1976. 
3. Scheuplein, R. J.: Percutaneous absorption after twenty-five years: or "old wine in new wine skins." J. Invest. Dermatol. 67:31, 1976.

4. Briggaman, R. A., Dalldorf, E. G., and Wheeler, C. E., Jr.: Formation and origin of basal lamina and anchoring fibrils in adult human skin. J. Cell Biol. $51: 384,1971$

5. Dodson, I. W.: The differentiation of epidermis. I. The interrelationship of epidermis and dermis in embryonic chicken skin. J. Embryol. Exp. Morphol. $17: 83,1967$

6. Dodson, J. W.: The differentiation of epidermis. II. Alternative pathways of differentiation of embryonic chicken epidermis in organ culture. I. Embryol. Exp. Morphol. 17:107, 1967.

7. Odland, G., and Ross, R.: Human wound repair. I. Epidermal regeneration J. Cell Biol. 39:135, 1968.

8. Croft, C. B., and Tarin, D.: Ultrastructural studies of wound healing in the mouse skin. I. Epithelial behavior. J. Anat. 106:63, 1970.

9. Gunson, D. E., and Kefalides, N. A.: The use of radioimmunoassay in the characterization of antibodies to basement membrane collagen. Immunology 31:563, 1976.

10. Heaphy, M. R., and Jordon, R. E.: Immunohistochemical studies of the human cutaneous basement membrane-anchoring fibril complex. J. Invest. Dermatol. 69:513, 1977.

11. Yaoita, H., Foidart, J. M., and Katz, S. I.: Localization of the collagenous component in skin basement membrane. J. Invest. Dermatol. 70:191, 1978.

12. Kefalides, N. A.: Structure and biosynthesis of basement membranes. Int. Rev. Connect. Tiss. Res. $6: 63,1973$.

13. Briggaman, R. A., and Wheeler, C. E., Ir.: The epidermal-dermal junction. J. Invest. Dermatol. $65: 71,1975$.

14. Trelstad, R. L., Hayaski, K., and Toole, B. P.: Epithelial collagens and glycosaminoglycans in the embryonic cornea; macromolecular order and morphogenesis in the basement membrane. J. Cell Biol. $62: 815,1974$

15. Cohn, R. H., Banersee, S. D., and Bernfield, M. R.: Basal lamina of embryonic salivary epithelia. $\mathrm{Na}$ ture of glycosaminoglycan and organization of extracellular materials. J. Cell Biol. 73:464, 1977.

16. Wolff, K., and Schreiner, E.: An electron microscopic study of the extracutaneous coat of keratinocytes and the intercellular space of the epidermis. J. Invest. Dermatol. 51:418, 1968.

17. Ohkubo, T., and Sano, S.: Functional aspects of the dermo-epidermal junction. Acta Derma. Venereol. 73:121, 1973.

18. Simon, R. S., Herndon, J. H., and Browne, R. H.: Permeability of the epidermaldermal junction zone in psoriasis and normal skin. Clin. Res. 25:101A. 1977 (abstract).

19. Kiistala, U., and Mustakallio, K. K.: Dermoepidermal separation with suction. Electron microscopic and histochemical study of initial events of blistering on human skin. J. Invest. Dermatol. $48: 466,1967$

20. Lowe, L. B., Ir., and van der Leun, I. C.: Suction blisters and dermalepidermal adherence. J. Invest. Dermatol. 50:308, 1968.

21. van der Leun, J. C., and Lowe, L. B.: The influence of skin temperature on dermal-epidermal adherence: Evidence compatible with a high viscous bond. J. Invest. Dermatol. 62:42, 1974.

22. Kiistala, U.: Dermal-epidermal separation. II. External factors in suction blister formation with special reference to the effect of temperature. Ann. Clin. Res. 4:236, 1972.

23. Peachey, R. D. G.: Skin temperature and blood flow in relation to speed of suction blister formation. $\mathrm{Br}$. J. Dermatol. 84:447, 1971.

24. Peachey, R. D. G.: Some factors affecting the speed of suction blister formation in normal subjects. $\mathrm{Br}$. . Dermatol. 84:435, 1971.

25. Kiistala, U.: Dermal-epidermal separation. I. The influence of age, sex, and body region on suction blister formation in human skin. Ann. Clin. Res. 4:10, 1972.

26. Diaz, L. A., Heaphy, M. R., Calvanico, N. J., Tomasi, T. B., and Jordon, R. E.: Separation of epidermis from dermis with sodium thiocyanate. J. Invest. Dermatol. 68:36, 1977.

27. Martinez-Palomo, A.: The surface coats of animal cells. Int. Rev. Cytol. 29:29, 1970.

28. Shienvold, F. L., and Kelly, D. E.: The hemidesmosome: new fine structural features revealed by freeze-fracture techniques. Cell Tiss. Res. 172:289, 1976.

29. Farbman, A. I.: Plasma membrane changes during keratinization. Anat. Rec. 156:269, 1966.

30. Odland, G. F.: The fine structure of the interrelationships in the human epidermis. J. Biophys. Biochem. Cytol. 4:529, 1958.

31. Bennedetti, E. L.. and Emmelot, P.: Studies on plasma membranes. IV. Ultrastructural localization and content of sialic acid in plasma membrane isolated from rat liver and hepatoma. I. Cell Sci. 2:499, 1967

32. Borysenko, J. Z., and Ravel, J. P.: Experimental manipulation of desmosome structure. Am. J. Anat. 137:403, 1973.

33. Overton, J.: Cell junctions and their development. Prog. Surf. Memb. Sci. 8:161, 1974.

34. Bennett, H. S.: Morphological aspects of extracellular polysaccharides. J. Histochem. Cytochem. 11:14, 1963.

35. Kelly, D. E., and Shienvold, F. L.: The desmosome: fine structural studies with freeze-fracture replication and tannic acid staining of sectioned epidermis. Cell Tiss. Res. 172:302, 1976

36. Douglas, W. H. J., Ripley, R. C., and Ellis, R. A.: Enzymatic digestion of desmosome and hemidesmosome plaques performed on ultrathin sections. J. Cell Biol. 44:211, 1970 .

37. Kelly, D. E.: Fine structure of desmosomes, hemidesmosomes and an adepidermal globular lever in developing newt epidermis. J. Cell Biol. 28:51, 1966

38. Matoltsy, G.: Desmosomes, filaments and keratohyaline granules: their role in the stabilization and keratinization of the epidermis. J. Invest. Dermatol. 65:127, 1975. 
39. Jarrett, A.: Normal epidermal keratinization. In:The Physiology and Pathophysiology of the Skin. Edited by Jarrett, A. New York, Academic Press, 1973, p. 161.

40. Rupec, M.: Die microtubuli der keratinocyten normaler menschlicher epidermis. Arch. Derm. Forsch. 249:235, 1974.

41. McGuire, J., Lazarides, E., and DiPasquale, A.: Keratinocytes contain actin. Clin. Res. 24:425, 1976 (abstract).

42. Bhatnagar, G. M., and Freedberg, I. M.: Contractile proteins from guinea pig epidermis: Isolation of myosin. Clin. Res. 25:527A, 1977 (abstract).

43. Steinert, P., Lichti, U., Yuspa, S., and Hennings, $H$.: Biochemical evidence for keratinization of mouse epidermal cells in culture. Clin. Res. 25:532, 1977 (abstract).

44. Frithiof, L.: Ultrastructural changes in the plasma membrane in human oral epithelium. J. Ultrast. Res. 32:1, 1970.

45. Allen, T. D., and Potten, C.: Desmosomal form, fate, and function in mammalian epidermis. J. UItrastruct. Res. 51:94, 1975.

46. Overton, J.: Experiments with junctions of the adhaerens type. In: Current Topics in Developmental Biology, vol. 10. Edited by Moscona, A. A., and Monroy, A. New York Academic Press, 1975, p. 1.

47. Wolff, K., and Wolff-Schreiner, E. C.: Trends in electron microscopy of skin. J. Invest. Dermatol. $67: 39,1976$

48. Beerens, E. G. J., Slot, J. W., and van der Leun, J. C. Rapid regeneration of the dermal-epidermal junction after partial separation by vacum: an electron microscopic study. J. Invest. Dermatol. 65:513, 1975.

49. Matoltsy, G.: What is keratin? In: Advance in Biology of the Skin. Edited by Montagna, W., and Dobson, R. L. New York, Meredith Corp. 1969, p. 559.

50. Singer, S. J., and Nicholson, G. L.: The fluid mosaic model of the structure of cell membrane. Science $175: 720,1972$

51. Worst, P. K. M., and Fusenig, N. E.: Histocompatibility Antigens on the Surface of Cultivated Epidermal Cells from Mouse Embryo Skin. Transplantation 15:375, 1973

52. Coombs, R. R. A., Bedford, D., and Rouillard, L. H.: $A$ and $B$ blood group antigens on human epidermal cells, as demonstrated by mixed agglutination. Lancet 1:641, 1956.

53. Holborow, E. J., Brown, P. C., Glynn, L. E., Hawes, M. D., Gresham, G. A., O'Brien, T. F., and Coombs, R. R. A.: The distribution of the blood $A$ antigen in human tissues. Br. J. Exp. Pathol. 41:430, 1960.

54. Szulman, A. E.: Histological distribution of blood group substances A and B in man. J. Exp. Med. 111:785, 1960.

55. Beutner, E. H., and Jordon, R. E.: Demonstration of skin autoantibodies in sera of pemphigus vulgaris patients by indirect immunoflourescence staining. Proc. Soc. Exp. Biol. Med. 117:505, 1964.

56. Hashimoto, K., King, L. E., Jr., Yamanishi, Y., Beachey, E. H., and Maeyens, E.: Identification of the substance binding pemphigus antibody and concanavalin A in the skin. J. Invest. Dermatol. $52: 423,1974$
57. Niedland, M. L.: Epidermal intercellular staining with fluoresceinconjugated phytohemagglutinins. J. Invest. Dermatol. 60:61, 1973.

58. Dabelsteen, E., Fejerskov, O., Norén, O., and Mackenzie, I. C.: Concanavalin A and ricinus communis receptor sites in normal human oral mucosa. J. Invest. Dermatol. 70:11, 1978.

59. Voorhees, J. J., Duell, E. A., Stawiski, M., and Harrell, R. E.: Cyclic Nucleotide Metabolism in Normal and Proliferating Epidermis. Adv. Cyclic Nucleot. Res. 4:117, 1974.

60. Sizuka, H., Adachi, K., Halprin, K. M., and Levine, V.: Histamine $\left(\mathrm{H}_{2}\right)$ receptor-adenylate cyclase system in pig skin (epidermis). Biochem. Biophys. Acta 437:150, 1976 .

61. Roseman, S.: The biosythesis of complex carbohydrates and their potential role in intercellular adhesion. In: The Cell Surface in Development. Edited by Moscona, A. A. New York, Wiley, 1974, p. 255.

62. Berlin, R. D., Oliver, J. M., Urena, T. E., and Yin, H. H.: The cell surface. New Engl. J. Med. 292:515, 1975.

63. Edelman, G. M.: Surface modulation in cell recognition and growth. Some new hypotheses on phenotypic alteration and transmembrane control of cell surface receptors. Science 192:218, 1976.

64. Nicolson, G.: Transmembrane control of receptors of normal and tumor cells. I. Cytoplasmatic influence over cell surface components. Bioch. Biophys. Acta 457:57, 1976.

65. Goldman, R. D., Berg, G., Bushnell, A., Chang, C. -M., Dickerman, L., Hopkins, N., Miller, M. L., Pollack, R., and Wang, E.: Fibrilar systems in cell motility. In: Locomotion of Tissue Cells (Ciba Foundation Symposium 14). North Holland, Elsevier-Excerpta Medica, 1973, p. 83.

66. Moscona, A. A.: Cell recognition, histotypic adhesion and enzyme induction in embryonic cells. In: Extracellular Matrix Influences on Gene Expression. Edited by Slavkin, H. C., and Greulich, R. C. New York, Academic Press, 1975, p. 57.

67. Mallucci, L., and Wells, V.: Determination of cell shape by cell surface protein component. Nature $262: 138,1976$

68. Strominger, J. L., and Mescher, M. F.: Structural (shape-maintaining) role of the cell surface glycoprotein of Halobacterium salinarium. Proc. Natl. Acad. Sci. USA 73:2687, 1976.

69. Tucker, J. B., and Meats, M.: Microtubules and control of insect egg shape. J. Cell Biol. 71:207, 1976.

70. Nicholson, G. L., Smith, J. R., and Poste, G.: Effects of local anesthetics on cell morphology and membrane-associated cytoskeletal organization in BALB/3T3 cells. J. Cell Biol. 68:395, 1976.

71. Willingham, M. C., Yamada, K. M., Yamada, S. S. Pouyssegur, J., and Pastan, I.: Microfilament bundles and cell shape are related to adhesiveness to substratum and are dissociable from growth control in cultured fibroblasts. Cell 10:375, 1977

72. Folkman, J., and Moscona, A.: Role of cell shape in growth control. Nature 273:345, 1978 .

73. Palian, I. U., and Hynes, R. O.: Effects of LETS Glycoprotein on cell motility. Cell 14:439, 1978.

74. Chen L. B., Murray, A., Segal, R. A., and Walsh, M. 
L.: Studies on Intercellular LETS Glycoprotein Matrices. Cell 14:377, 1978.

75. Pouyssegur, J., Willingham, M., and Pastan, I.: Role of cell surface carbohydrates and proteins in cell behavior: Studies on the biochemical reversion of an $\mathrm{N}$-acetylglycosamine-deficient fibroblast mutant. Proc. Natl. Acad. Sci. USA. 74:243, 1977

76. Yamada, K. M., Yamada, S. S., and Pastan, I.: Cell surface protein partially restores morphology, adhesiveness, and contact inhibition of movement to transformed fibroblasts. Proc. Natl. Acad. Sci. USA 73:1217, 1976.

77. Nicolson, G.: Transmembrane control of receptors of normal and tumor cells. II. Surface changes associated with transformation and malignancy. Biochem. Biophys. Acta 458:1, 1976.

78. Nicolson, G., and Poste, G.: The cancer cell: dynamic aspects and modifications in cell-surface organization. I. N. Engl. J. Med. 295:197, 1976., II. N. Engl. J. Med. 295:253, 1976.

79. Hynes. R. O.: Cell surface proteins and malignant transformation. Biochem. Biophys. Acta 458:73, 1976.

80. Cassiman, J. J., and Bernfield, M. R.: Transformation-induced alteration in adhesion. Binding of pre-formed cell aggregates to cell layers. Exp. Cell Res. 103:311, 1976.

81. Pastan, I., and Willingham, M.: Cellular transformation and the morphologic phenotype of transformed cells. Nature 274:645, 1978.

82. Staehelin, L. A.: Structure and function of intercellular junctions. Int. Rev. Cytol. 39:191, 1974.

83. Overton, J.: Experimental manipulation of desmosome formation. J. Cell Biol. 56:636, 1973.

84. Breathnach, A. S., and Wyllie, L. M. A.: The problem of the Langerhans cells. In: Advances in Biology of the Skin, vol. 8. Edited by Montagna, W., and Hu, F. New York, Pergamon Press, 1967, p. 97.

85. Tyler, A.: An auto-antibody concept of cell structure, growth and differentiation. Growth (Symposium) 10:7, 1946

86. Weiss, P. A.: The problem of specificity in growth and development. Yale J. Biol. Med. 19:235, 1947.

87. Roseman, S.: The synthesis of complex carbohydrates by multiglycosyltransferance systems and their potential function in intercellular adhesion. Chem. Phys, Lipids 5:270, 1970.

88. Bell, G. I.: Models for the specific adhesion of cell to cells. A theoretical framework for adhesion mediated by reversible bonds between cell surface molecules. Science 200:618, 1978.

89. Roseman, S., Rottman, W., Walther, B., Ohman, R. and Umbreit, J.: Measurement of cell-cell interactions. In: Methods in Enzymology, Vol. 32. Edited by Fleischer, S., and Packer. New York, Academic Press, 1974, p. 597.

90. Grinnell, F.: Cellular adhesiveness and extracellular substrata. Int. Rev. Cytol. 53:65, 1978.

91. Grinnell, F.: Biochemical analysis of cell adhesion to a substratum and its possible relevance to cell metastasis. In: Membranes and Neoplasia New Approaches and Strategies. Edited by Marchesi, V. F. New York, Alan R. Liss Inc., 1976, p. 227

92. Taylor, A. C.: Attachment and spreading of cells in culture. Exp. Cell Res. Suppl. 8:154, 1961.
93. Grinnell, F.: Cell spreading factor. Occurrence and specificity of action. Exp. Cell Res. 102:51, 1976.

94. Klebe, R. J., Rosenberger, P. G., Naylor, S. L., Burns, R. L., Novak, R., and Kleinman, H.: Cell attachment to collagen. Isolation of a cell attachment mutant. Exp. Cell Res. 104:119, 1977.

95. Rosenberg, M. D.: Microexudates from cells grown in tissue culture. Biophys. J. 1:137, 1960.

96. Culp, L. A.: Substrate-attached glycoproteins mediating adhesion of normal and virustransformed mouse fibroblasts. J. Cell Biol. 63:71, 1974.

97. Weiss, L., Poste, G., MacKearin, A., and Willett, K.: Growth of mammalian cells on substrates coated with cellular microexudates. J. Cell Biol. 64:135. 1975.

98. Millis, A. J. T., and Hoyle, M.: Fibroblastconditioned medium contains cells surface proteins required for cell attachment and spreading. Nature 271:668, 1978.

99. Steinberg, M. S.: On the chemical bonds between animal cells: a mechanism for type specific association. Am. Naturalist 92:65, 1958.

100. Klebe, R. J.: Cell attachment to collagen: the requirement for energy. J. Cell Physiol. 231, 1975.

101. Takeich, M.: Functional correlation between cell adhesive properties and some cell surface proteins. J. Cell Biol. 75:464, 1977.

102. Moscona, A. A.: Surface specification of embryonic cells: lectin receptors, cell recognition and specific cell ligands. In: The Cell Surface in Development. Edited by Moscona, A. A. New York, Wiley, 1974, p. 67.

103. Ueda, M. J., Ito, T., Okada, T. S., and Ohnish, S-I.: A correlation between membrane fluidity and the critical temperature for cell adhesion. J. Cell Biol. 71:670, 1976.

104. Lin, P-S., Butterfield, C. E.: Hyperthermic treatment $\left(43^{\circ} \mathrm{C}\right)$ rapidly impedes attachment of fibroblasts to culture substrates. Cell Biol. Int. Rep. 1:57, 1977.

105. Moscona, A. A.: Cell aggregation properties of specific cell-ligands and their role in the formation of multicellular systems. Dev. Biol. 18:250, 1968.

106. Lilien, J. E.: Specific enhancement of cell aggregation in vitro. Dev. Biol. 17:657, 1968.

107. Daday, H., and Creaser, E. H.: Isolation of a protein responsible for aggregation of avian embryonic cells. Nature 226:970, 1970.

108. Kondo, K., and Sakai, H.: Demonstration and preliminary characterization of reaggregation promoting substances from embryonic sea urchin cell. Dev. Growth Diff. 13:1, 1971.

109. Oppenheimer, S. B., and Humphrey, T.: Isolation of specific macromolecules required for adhesion of mouse tumor cells. Nature 232:125, 1971.

110. Garber, B. B., and Moscona, A. A.: Reconstruction of brain tissue from cell suspensions. II. Specific enhancement of aggregation of embryonic cerebral cells by supernatant from homologous cell cultures. Dev. Biol. 27:235, 1972 .

111. McClay, D. R., and Moscona, A. A.: Purification of the specific cell-aggregating factor from embryonic neural retina cells. Exp. Cell Res. 87:438, 1974.

112. Tonegawa, Y.: Isolation and characterization of a particulate cell-aggregation factor from sea urchin embryos. Dev. Growth Diff. 14:327, 1973. 
113. Merrel, R., and Glaser, L.: Specific recognition of plasma membranes by embryonic cells. Proc. Natl. Acad. Sci. USA 70:2784, 1973.

114. Obrink, B., Kuhlenschmidt, M. S., and Roseman, S.: Adhesive specificity of juvenile rat and chicken liver cells and membranes. Proc. Natl. Acad. Sci. USA 74:1077, 1977

115. Santala, R., Gottlieb, D. I., Littman, D., and Glasser, L.: Selective cell adhesion of neuronal cell lines. J. Biolog. Chem. 252:7625, 1977.

116. Reitherman, R. W., Rosen, S. D., Frazier, W. A., and Borondes, S. H.: Cell surface specie-specific high affinity receptors for discoidin: development regulation in Dictyostelim discoideum. Proc. Natl. Acad. Sci. USA 72:3541, 1975.

117. Yamada, K. M., Yamada, S. S., and Pastan, I.: The major cell glycoprotein of chicken embryo fibroblasts is an agglutinin. Proc. Natl. Acad. Sci. USA $72: 3158,1975$.

118. Yamada, K. M., and Olden, K.: Fibronectinsadhesive glycoproteins of cell surface and blood. Nature 275:179, 1978.

119. Yamada, K. M.: Immunologic characterization of a major transformation-sensitive fibroblast cell surface glycoprotein. Localization, redistribution and role in cell shape. J. Cell Biol. 78:520, 1978.

120. Pearlstein, E.: Plasma membrane glycoprotein which mediates adhesion of fibroblasts to collagen. Nature 262:497, 1976.

121. Edwards, J. G., Dysart, J. Mck., and Hughes, R. C. Cellular adhesiveness reduced in recin-resistant hamster fibroblasts. Nature 264:66, 1966.

122. Mautner, V., and Hynes, R. O.: Surface distribution of LETS protein in relation to the cytoskeleton of normal and transform cells. J. Cell Biol. 75:743, 1977.

123. Rutishauser, U., Thiery, J. P., Brackenbury, R., Sela, B. A., and Edelman, G. D.: Mechanisms of adhesion among cells from neural tissues of chick embryo. Proc. Natl. Acad. Sci. USA 73:577, 1976.

124. Brackenbury, R., Thiery, J-P., Rutishauser, U., and Edelman, G. M.: Adhesion among neural cells of the chick embryo. I. An immunological assay for molecules involved in cell-cell binding. J. Biolog. Chem. 252:6835, 1977

125. Thiery, J-P., Brackenbury, R., Rutishauser, U., and Edelman, G. M.: Adhesion among neural cells of the chick embryo. II. Purification and characterization of a cell adhesion molecule from neural retina J. Biolog. Chem. 252:6841, 1977.

126. Hoffman, S., and McMahon, D.: Defective glycoproteins in the plasma membrane of an aggregation minus of dictyostelium discoideum with abnormal cellular interactions. J. Biolog. Chem. 253:278, 1978.

127. Juliano, R. L.: Adhesion and detachment characteristics of chinese hamster cell membrane mutants. J. Cell Biol. 76:43, 1978.
128. Burridge, K.: Changes in cellular glycoproteins after transformation: identification of specific glycoproteins and antigens in sodium dodecyl sulfate gels. Proc. Natl. Acad. Sci. USA 73:4457, 1976.

129. Chen, L. B., Gallimore, P. H., and McDougall, J. K.: Correlation between tumor induction and the large external transformation sensitive protein on the cell surface. Proc. Natl. Acad. Sci. USA 73:3570, 1976.

130. Easton, J. M., Goldberg, B., and Green, H.: Immune cytolysis: electron microscopic localization of cellular antigens with ferritin-antibody conjugates. J. Exp. Med. 115:275, 1962.

131. Rieber, M., and Romano, E.: Transformationdependent modification in released and cell-bound surface proteins detected by antisera to shed antigens. Cancer Res. 36:3568, 1976.

132. Liang, W., and Cohen, E. P.: The effects of specific antiserum on the metabolism of three membraneassociated antigens of ASL-1X LM (TK) ${ }^{-}$hybrid cells. Somat. Cell Genet. 2:291, 1976.

133. Carey, F. J., Kuhn, N. O., and Harford, C. G.: Effects of anticellular serum on phagocytosis and the uptake of tritiated thymidine and uridine by HeLa cells. I. Exp. Med. 121:991, 1965.

134. Carey, F. J., and Pettengil, O. S.: Time-lapse study of effects of antibody in membrane mobility and phagocytic activity of HeLa cells. J. Cell Biol. 33:709, 1967.

135. O'Neill, C. H., and Follett, E. A. C.: An inverse relation between cell density and the number of microvilli in cultures of BHK 21 hamster fibroblasts. J. Cell Sci. 7:695, 1970.

136. Rosen, S. D., Haywood, P. L., and Barondes, S. H.: Inhibition of intercellular adhesion in a cellular slime mold by univalent antibody against a cell-surface lectin. Nature 263:425, 1976.

137. Beug, H., Katz, F. E., and Gerisch, G.: Dynamics of antigenic membrane sites relating to cell aggregation in dyctyostelium discoideum J. Cell Biol. $56: 647,1973$

138. Muller, K., and Gerisch, G.: A specific glycoprotein as the target site of adhesion blocking Fab in aggregating dictyostelium cells. Nature 274:445, 1978.

139. Kemler, R., Babinet, C., Eisen, H., and Jacob, F.: Surface antigen in early differentiation. Proc. Matl. Acad. Sci. USA 74:4449, 1978.

140. Loewenstein, W. R.: Cell coupling. In: Transport Mechanisms in Epithelia. Edited by Ussing, H. H., and Thorn, N. A. Munksgaard Copenhagen, 1973, p. 20.

141. Pisam, M., and Ripoche, P.: Redistribution of surface macromolecules in dissociated epithelial cells. J. Cell Biol. 71:907, 1976.

142. Terasaki, P.I., and Chamberlain, C. C.: Destruction of epidermal cells in vitro by autologous serum from normal animals. J. Exp. Med. 115:439, 1962. 
This document is a scanned copy of a printed document. No warranty is given about the accuracy of the copy. Users should refer to the original published version of the material. 